EETP Vol. 16, 2021, №. 2(60)

ISSN 1896-2327 / e-ISSN 2353-7787

DOI: $10.35765 /$ eetp.2021.1660.06

Nadesłano: 8.03.2021

Zaakceptowano: 8.05.2021

Sugerowane cytowanie: Surma B. (2021). Implementacja modelu kształcenia nauczycieli przedszkoli i edukacji wczesnoszkolnej w Polsce, „Edukacja Elementarna w Teorii i Praktyce", vol. 16, nr 2 (60), s. 77-88. DOl: 10.35765/eetp.2021.1660.06

\title{
Implementacja modelu kszłałcenia nauczycieli przedszkoli i edukacji wczesnoszkolnej w Polsce
}

\author{
Implementation of the Model of Educating Pre-School \\ and Early School Teachers in Poland
}

\section{SŁOWA KLUCZE ABSTRAKT}

proces kształcenia nauczycieli, reforma

szkolnictwa wyższego, kwalifikacje nauczycielskie, kompetencje nauczycielskie, nauczyciel przedszkolny i wczesnoszkolny
Reforma szkolnictwa wyższego w Polsce zmienia system i standardy kształcenia nauczycieli przedszkoli i edukacji wczesnoszkolnej. Od opublikowania w 2019 roku „Rozporządzenia Ministra Nauki i Szkolnictwa Wyższego w sprawie standardu kształcenia przygotowującego do wykonywania zawodu nauczyciela” (Dz.U. 2019 poz. 1450), zaczęto wprowadzać zmiany, które obejmują przeniesienie procesu kształcenia nauczycieli z systemu dwuetapowego na system jednolitych studiów magisterskich. Zmiany w systemie kształcenia zostały poprzedzone opracowaniem modelu kształcenia oraz wdrażaniem programów w ramach projektów dofinansowanych ze środków europejskich. Celem tego artykułu jest przybliżenie i ocena założeń „Propozycji modelu kształcenia nauczycieli przedszkolnych i wczesnoszkolnych” (z roku 2018) na przykładzie implementacji projektu zatytułowanego „Eksperymentalny program kształcenia nauczycieli przedszkoli i edukacji wczesnoszkolnej w Akademii Ignatianum w Krakowie" oraz wskazanie istotnych różnic między wstępnymi założeniami, które obecnie są wdrażane w formie eksperymentu na kilku uczelniach, a obowiązującymi od 2019 roku ministerialnymi wytycznymi. Po krótkim wprowadzeniu i nakreśleniu aktualnej 
sytuacji wskazano główne przyczyny, jakimi kierowano się w opracowaniu nowych wytycznych, które zostały ocenione. Zmiany w procesie kształcenia nauczycieli mają przyczynić się do podniesienia jakości ich przygotowania, co zostało uwzględnione w obu wspomnianych i analizowanych dokumentach.

\section{KEYWORDS ABSTRACT}

teacher education process, higher education reform, teaching qualifications, teaching competences, preschool and early school teacher
The reform of higher education in Poland changes the system and standards of educating pre-school and early school teachers. Since the publication, in 2019, of the "Regulation of the Minister of Science and Higher Education on the standard of education preparing for the teaching profession" (Journal of Laws 2019, item 1450), changes have been introduced, which include the transfer of the teacher education process from a two-stage system to the system of uniform studies ending with a master's degree. Changes in the teacher training were preceded by the development of a specific education model and the implementation of programs under various projects co-financed from European funds. The aim of this article is to present and evaluate the assumptions of the "Proposed model of educating pre-school and early school teachers" (from 2018), based on the example of the implementation of the project entitled "Experimental curriculum for training kindergarten and early school teachers at the Jesuit University Ignatianum in Krakow", and to indicate significant differences between the initial assumptions, which are currently being implemented as an experiment at several universities, and the ministerial guidelines in force since 2019. After a brief introduction and outline of the current situation, the main reasons for the development of the new guidelines (that were assessed) have been identified. Changes in the teacher education process are to contribute to the improvement of the quality of their preparation, which was taken into account in both of the above-mentioned and analysed documents.

\section{Wprowadzenie}

W roku 2019 opublikowano „Rozporządzenie Ministra Nauki i Szkolnictwa Wyższego w sprawie standardu kształcenia przygotowującego do wykonywania zawodu nauczyciela" (Dz.U. 2019 poz. 1450), w tym nauczyciela przedszkola i edukacji wczesnoszkolnej (klasy I-III szkoły podstawowej) zmieniające rozporządzenie z dnia 17 stycznia 2012 roku (Dz.U. 2012 poz. 131). Zmiany te zostały poprzedzone opracowaniem nowego modelu kształcenia nauczycieli przedszkoli i edukacji wczesnoszkolnej, realizowanym w ramach projektu ogłoszonego przez Ministra Nauki 
i Szkolnictwa Wyższego, który był współfinansowany ze środków Unii Europejskiej w ramach Europejskiego Funduszu Społecznego ogłoszonego w latach 2016-2017. Opracowany przez zespół przy MNiSW dokument „Propozycja nowego modelu kształcenia nauczycieli przedszkoli i edukacji wczesnoszkolnej” został ogłoszony 31 stycznia 2018 roku. Był on konsultowany ze środowiskiem akademickim podczas siedmiu spotkań diagnozujących i szesnastu spotkań konsultacyjnych organizowanych w kilku miastach na terenie Polski. Ich celem było, jak podano na stronie ministerstwa, uzgodnienie ostatecznej wersji programu (https://www.gov.pl/web/edukacja-i-nauka/opracowanie-modelowych-programow-ksztalcenia-nauczycieli-w-ramach-dzialania-31-kompetencje-w-szkolnictwie-wyzszym).

Kolejnym etapem było ogłoszenie konkursu Narodowego Centrum Badań i Rozwoju nr POWR.03.01.00-IP.08-00-PKN/18 na „Programy kształcenia nauczycieli”, dotyczącego opracowania i wdrożenia programów kształcenia nauczycieli na kierunkach realizujących specjalność nauczycielską. O dofinansowanie z Programu Operacyjnego Wiedza Edukacja Rozwój (PO WER) mogły się ubiegać projekty realizowane wyłącznie na kierunkach studiów ze specjalnością nauczycielską oraz oparte na wytycznych zatwierdzonych przez MNiSW dotyczących kształcenia nauczycieli, oraz nauczycieli przedszkolnych i wczesnoszkolnych. Głównym celem tego projektu było podniesienie kompetencji studentów, którzy zamierzają w przyszłości zostać nauczycielami. Opracowanie programów kształcenia nauczycieli na podstawie „Propozycji modelu..." i ich wdrożenie stanowić miało pewnego rodzaju eksperyment, którego realizacja miała zweryfikować założenia zapisane w wyżej wymienionym dokumencie.

Do konkursu przystąpiło 67 uczelni, których wnioski zostały poddane ocenie (https://archiwum.ncbr.gov.pl/fileadmin/POWER/03.01...PKN_18/zal._nr_6_Lista_rankigowa_pozytywna_PKN.pdf). W pierwszym etapie oceniono pozytywnie 56 wniosków, w tym 19, które opracowały programy kształcenia nauczycieli przedszkolnych i wczesnoszkolnych. 8 stycznia 2019 roku ogłoszono dodatkową listę ze wskazaniem jednej uczelni, której przyznano dofinansowanie, po pozytywnym rozpatrzeniu złożonego przez nią protestu.

Ze względu na krótki czas na składanie wniosku i otrzymanie decyzji o przyznaniu środków uczelnie miały do wyboru opracowanie programów kształcenia zgodnie z obowiązującymi wytycznymi. Warunkiem była realizacja projektu w terminie od października 2018 roku do września 2023 roku. Istotne jednak było to, żeby w ramach projektu uczestnicy/studenci uzyskali kwalifikacje potwierdzone dyplomem ukończenia studiów w terminie do 30 września 2023 roku (ukończenia przynajmniej jednego stopnia). Dlatego opracowanie i wdrożenie programu w systemie jednolitych studiów magisterskich należało rozpocząć w październiku 2018 roku. Studia dla nauczycieli przedszkolnych i wczesnoszkolnych mogły być realizowane tylko na kierunku pedagogika przedszkolna i wczesnoszkolna. Wymogu tego nie spełniała większość 
uczelni składających wniosek o dofinansowanie. Do konkursu mogły przystąpić również uczelnie, które przed 2018 rokiem prowadziły studia nauczycielskie na kierunku pedagogika. Alternatywą bowiem była możliwość opracowania programu w systemie 3+2 na kierunku pedagogika ze specjalnością pedagogika przedszkolna i wczesnoszkolna. Mając na uwadze zasady ogłoszonego konkursu, część wnioskodawców zaplanowała rozpoczęcie projektu w późniejszym terminie i opracowała program studiów dla I stopnia lub II stopnia. Uczelnie, które miały rozpocząć swoje projekty w październiku 2019 roku na kierunku pedagogika, ze względu na wprowadzaną reformę szkolnictwa wyższego, musiały ponownie przystąpić do negocjacji, które rozstrzygnięto 4 lutego 2019 roku. Dofinasowanie otrzymały 23 uczelnie. Niektóre z nich realizują program kształcenia nauczycieli w czasie krótszym niż wymagane pełne dziesięć semestrów. Część zrezygnowała z podpisania umowy.

Celem tego artykułu jest przybliżenie i ocena założeń „Propozycji modelu kształcenia nauczycieli przedszkolnych i wczesnoszkolnych” (z 2018 r.) na przykładzie implementacji projektu zatytułowanego „Eksperymentalny program kształcenia nauczycieli przedszkoli i edukacji wczesnoszkolnej w Akademii Ignatianum w Krakowie”. Projekt uzyskał dofinasowanie na opracowanie programu i jego wdrożenie, początkowo na kierunku pedagogika w systemie studiów I i II stopnia. Ze względu na reformę szkolnictwa wyższego i uzyskanie zgody na utworzenie kierunku pedagogika przedszkolna i wczesnoszkolna, projekt od 2020 roku jest realizowany w systemie jednolitych studiów magisterskich. Celem też jest porównanie zapisów w rozporządzeniu ministra nauki i szkolnictwa wyższego w sprawie standardu kształcenia przygotowującego do wykonywania zawodu nauczyciela (Dz.U. 2021 poz. 312) z „Propozycją modelu kształcenia nauczycieli przedszkolnych i wczesnoszkolnych" i wskazanie istotnych różnic między wstępnymi założeniami, które obecnie są wdrażane w formie eksperymentu na kilku uczelniach, a obowiązującymi od 2019 roku ministerialnymi wytycznymi.

\section{Przyczyny zmian w systemie kształcenia nauczycieli przedszkolnych i wczesnoszkolnych w Polsce}

Reforma szkolnictwa wyższego, a zwłaszcza ta dotycząca wprowadzenia radykalnych zmian $\mathrm{w}$ procesie kształcenia nauczycieli podyktowana była postulatami środowiska akademickiego oraz wynikami badań. Między innymi wskazywały one, że system kształcenia podzielonego na dwa etapy oraz zróżnicowanie wymagań wobec nauczycieli elementarnej edukacji i kolejnych poziomów szkół (rozporządzenie MEN z 12 marca 2009 r. w sprawie szczegółowych kwalifikacji wymaganych od nauczycieli) „wprowadziło zamęt i niejednoznaczność w interpretowaniu kwalifikacji zdobywanych na I i na II stopniu studiów (zgodnie z wymaganiami rozporządzenia MNiSW 
z 17 stycznia 2012 r. w sprawie standardów kształcenia przygotowującego do wykonywania zawodu nauczyciela)" (Gołębniak, Krzychała 2015: 100).

System studiów podzielony na dwa stopnie opierał się na uzyskaniu efektów kształcenia w oparciu o pięć modułów: (1) Przygotowanie w zakresie merytorycznym do nauczania pierwszego przedmiotu zgodne z kierunkiem studiów; (2) Przygotowanie w zakresie psychologiczno-pedagogicznym; (3) Przygotowanie w zakresie dydaktycznym; (4) Przygotowanie do nauczania kolejnego przedmiotu; (5) Przygotowanie w zakresie pedagogiki specjalnej. Treści przyporządkowane do pierwszych trzech modułów należało realizować zarówno na studiach I stopnia, jak i na studiach II stopnia (lub studiach podyplomowych). Studenci mogli zdobyć kwalifikacje do nauczania różnych przedmiotów, na każdym stopniu innego. Najważniejsze jednak było ukończenie modułu z zakresu przygotowania psychologiczno-pedagogicznego i dydaktycznego, który dawał kwalifikacje do wykonywania zawodu nauczyciela. Dlatego absolwenci kończący inne specjalności mogli uzyskać kwalifikacje nauczycielskie w trakcie dwuletnich studiów magisterskich lub na studiach podyplomowych (trwających trzy semestry). Uczelnie były zobowiązane tak planować program studiów II stopnia i podyplomowych, by studenci mogli uzyskać (uzupełnić) kwalifikacje. Przy założeniu, że w pierwszych dwóch semestrach realizowane muszą być treści wprowadzające (często luźno powiązane z przedmiotem kierunkowym), czas na specjalizację ograniczał się do zajęć w drugim roku studiów II stopnia. Zbyta mała liczba godzin, ale także zbyt duże zróżnicowanie między studentami, którzy kończyli różne kierunki i specjalności, również nie sprzyjały podnoszeniu jakości ich wykształcenia. Jedynym plusem posiadania dyplomów potwierdzających różne kwalifikacje było zwiększenie szansy ich zatrudnienia.

Kształcenie modułowe w systemie 3+2, zwłaszcza nauczycieli przedszkolnych i wczesnoszkolnych, niestety w praktyce się nie sprawdziło. Studenci po ukończeniu studiów licencjackich ze specjalnością pedagogika przedszkolna i wczesnoszkolna, często wybierali inną specjalność na studiach magisterskich. Absolwenci uważali, że kontynuacja tej samej specjalności, mimo że w programach zakładano pogłębianie i poszerzanie wiedzy i umiejętności, będzie powtarzaniem tych samych treści i stratą czasu. Niestety często mieli rację. Było to spowodowane potrzebą wyrównywania poziomu studentów, kończących inny kierunek czy specjalność. Zróżnicowanie poziomu wiedzy merytorycznej studentów II stopnia często nie pozwalała na jej pogłębianie, co było założeniem modułowego kształcenia przyszłych nauczycieli w systemie $3+2$. Krytykowano również rozdzielenie przygotowania merytorycznego, dydaktycznego i psychologiczno-pedagogicznego, które stanowiło dla badanych nauczycieli akademickich „swoistą sytuację bezradności” (Gołębniak, Krzychała 2015: 106).

Wprowadzenie zmian podyktowane było potrzebą podniesienia jakości przygotowania zawodowego nauczycieli, które powinno sprostać wymogom obecnych czasów. 
Współczesny nauczyciel powinien być wielostronny i wielowymiarowy. Jednakże w praktyce nie oznaczało to posiadania kompetencji w zakresie teorii kształcenia wielostronnego, ale raczej przygotowania do prowadzenia wielu przedmiotów, często bardzo odległych od tego podstawowego (Pawelec 2017: 102). Nauczyciel powinien zdobyć kwalifikacje przedmiotowo-dydaktyczne, metodyczne, do organizowania samodzielnej pracy w grupach, w zakresie diagnozowania, doradztwa oraz metakwalifikacje obejmujące samoobserwację i samoocenę, a także dotyczące korzystania z technologii informacyjnej i komunikacyjnej (Surma 2011: 161). Nauczyciel przedszkolny w ostatnich latach został dodatkowo zobligowany do zdobycia kwalifikacji do nauczania języka obcego i prowadzenia zajęć w ramach swojego pensum.

Zwracano też uwagę, że w procesie kształcenia nauczyciel powinien nabyć kompetencje poznawcze (autorefleksyjne), które odzwierciedlają się w postawie otwartości na informacje o sobie i o świecie oraz umiejętnością i gotowością do zaktualizowanego posługiwania się nimi (Czerepaniak-Walczak 1997: 92). Kolejnymi oczekiwanymi kompetencjami są: diagnostyczne, wychowawczo-dydaktyczne (nauczyciel ma być organizatorem procesu edukacyjnego, koordynatorem całokształtu życia i aktywności dzieci, inicjatorem i stymulatorem procesów rozwojowych, partnerem wspomagającym indywidualny rozwój dziecka), interpersonalne i innowacyjne.

Praca w przedszkolu i w klasach I-III wymaga przygotowania interdyscyplinarnego i aby temu sprostać, należało wprowadzić zmiany w procesie kształcenia nauczycieli, które uwzględniałyby zarówno uzyskanie kwalifikacji zawodowych, jak i niezbędnych kompetencji.

Przytoczone powyżej wybrane postulaty stały się podstawą dla opracowania i wdrożenia zmian, które zaczęły obowiązywać od roku akademickiego 2019/2020. Pierwszą zmianą jest przeniesienie procesu kształcenia nauczycieli przedszkolnych i wczesnoszkolnych z kierunku pedagogika na kierunek pedagogika przedszkolna i wczesnoszkolna. Drugą zmianą jest zlikwidowanie dwuetapowego systemu kształcenia. Możliwość rekrutacji na studia II stopnia kończy się w roku akademickim 2021/2022. Proces kształcenia w systemie jednolitych studiów magisterskich powinien trwać co najmniej dziewięć semestrów. Zlikwidowano możliwość uzyskania kwalifikacji nauczycielskich na studiach podyplomowych. Oprócz tych zmian zaproponowano również nowe standardy kształcenia, które zostaną przybliżone w dalszej części artykułu. 


\section{Założenia nowego modelu kszłałcenia nauczycieli przedszkolnych i wczesnoszkolnych i ocena na przykładzie programu realizowanego w Akademii Ignatianum w Krakowie}

W analizowanym dokumencie „Propozycja nowego modelu...” z 2018 roku w opisie sylwetki absolwenta opisano oczekiwane postawy przyszłych nauczycieli, które ujęto w ośmiu kategoriach. Wyznaczają one kierunek działań przyporządkowanych do dziewięciu modułów realizowanych liniowo w cyklu pięcioletnich studiów, plus jeden dodatkowy modul, dotyczący indywidualnego wsparcia studentów. Założono, że zajęcia spersonalizowane z elementami tutoringu przypisane do tego modułu mają trwać przez cały okres studiów w wymiarze 20 godzin na jednego studenta. Kształtowane oczekiwane postawy przyporządkowano do dwóch obszarów. Pierwszy z nich to obszar wiedzy i umiejętności o charakterze profesjonalnym, drugi to obszar kształtowania relacji wobec siebie i innych.

Osoba przygotowana do wykonywania zawodu nauczyciela według zapisu w tym dokumencie ma być: refleksyjnym praktykiem, ekspertem od wspierania rozwoju dziecka i erudytą (pierwszy obszar) oraz spolegliwym opiekunem, członkiem zespołu/ów, człowiekiem pozytywnie nastawionym do nowych doświadczeń, osobą mającą świadomość swoich zainteresowań, a także uczciwym człowiekiem (obszar drugi) (Propozycja nowego modelu... 2018: 1-2). Postawy te wynikają z oczekiwanych kompetencji, które opisane zostały w literaturze przedmiotu.

W dokumencie sformułowane zostały ogólne (w liczbie 9) i szczegółowe efekty kształcenia (wiedza: 19; umiejętności: 16; w zakresie kompetencji społecznych: 10), które korelują z opisem oczekiwanych postaw. Oprócz wyodrębnienia efektów w zakresie wiedzy, umiejętności, kompetencji społecznych i interpersonalnych, wyszczególniono dodatkowo efekty w zakresie własnego rozwoju (4), technologii informacyjnej i komunikacyjnej (TIK) oraz informatyki (4), a także w zakresie języka obcego (zgodnie z Polską Ramą Kwalifikacji dla Szkolnictwa Wyższego). Rozkład ilościowy i jakościowy efektów w stosunku do planowanych przedmiotów był nierównomierny (jedne były bardzo liczne i uszczegółowione, inne zbyt ogólne), co stanowiło pewien problem w opracowaniu programu kształcenia i doboru odpowiednich efektów do treści przedmiotowych.

Najistotniejsze jednak kwestie zostały uwzględnione w dokumencie, który dał podstawę prawną do wprowadzenia zmian dotyczących uczenia się w działaniu oraz personalizacji procesu kształcenia nauczycieli w ramach realizacji projektu/eksperymentu. Otrzymanie dofinansowania umożliwiło zwiększenie liczby godzin na realizację poszczególnych grup przedmiotów, zgodnie z „Propozycją modelu kształcenia...”. 
W dokumencie zwrócono uwagę na skorelowanie treści kształcenia (wiedza i umiejętności) zdobywanych w ramach zajęć na uczelni z uczeniem się w działaniu poprzez zwiększenie minimalnej liczby godzin praktyk z 270 do 300. Stworzono możliwość rozpoczęcia praktyk już w pierwszym roku studiów. Połączenie podstaw pedagogiki, podstaw pedagogiki przedszkolnej i wczesnoszkolnej oraz podstaw psychologii dla nauczycieli, w pierwszym module, i ukierunkowanie treści tych przedmiotów na kwestie edukacyjne pozwoliły uniknąć chaosu i dały solidne podstawy do merytorycznego przygotowania studentów do dalszego procesu kształcenia. Personalizacja procesu kształcenia oraz uczenie się w działaniu wiązały się ze zwiększeniem liczby ćwiczeń i zmniejszeniem liczby studentów w grupach. W module drugim zaplanowano realizację podstaw edukacji i metodykę poszczególnych przedmiotów w przedszkolu i klasach I-III. Wyodrębnienie podstaw edukacji muzycznej, technicznej, plastycznej, a także metodyk dla tych przedmiotów, dało okazję do zdobycia przez studentów umiejętności artystycznych, tak potrzebnych w pracy z dziećmi. Przewidywana liczba godzin na realizację innowacyjnego programu kształcenia nauczycieli przedszkolnych i wczesnoszkolnych wynosiła 3590 godzin, plus 20 godzin na zajęcia spersonalizowane.

Przybliżone przeze mnie wybrane założenia stały się podstawą do opracowania nowego, eksperymentalnego programu kształcenia nauczycieli przedszkolnych i wczesnoszkolnych, który od roku akademickiego 2018/2019 jest stopniowo wdrażany na Wydziale Pedagogicznym Akademii Ignatianum w Krakowie. Na podstawie wywiadów z nauczycielami akademickimi i obserwacji można stwierdzić, że praca w małych grupach (od 7 do 15 osób) i objęcie uczestniczek projektu indywidualnym wsparciem w ramach spersonalizowanych zajęć z elementami tutoringu przynosi pozytywne efekty w wielu obszarach. Studentki stają się coraz bardziej świadomymi nauczycielami i refleksyjnymi praktykami poszukującymi innowacyjnych rozwiązań w pracy z dziećmi. Biorą udział w szkoleniach i warsztatach, które dodatkowo oferuje im uczelnia, i nie tylko.

Jednym z priorytetów programu było przygotowanie studentek do uzyskania umiejętności językowych i kwalifikacji do nauczania języka obcego w przedszkolu. Zwiększenie liczby godzin na zajęcia z lektoratu i praca w siedmioosobowych grupach przyczyniła się do zdobycia wysokiego poziomu posługiwania się językiem angielskim.

Przygotowanie do prowadzenia zajęć z matematyki, przyrody, języka polskiego, wychowania społeczno-moralnego, plastycznego, technicznego, muzycznego, fizycznego jest realizowane w dwóch modułach: w ramach przygotowania do integracji treści i metodyk poszczególnych typów edukacji z uwzględnieniem sposobów integrowania wiedzy i umiejętności dzieci/uczniów. Na przedmioty z podstaw edukacji było przeznaczone 600 godzin, 400 godzin na poznanie sposobów wspierania rozwoju dzieci w wieku przedszkolnym, a na zajęcia z metodyk poszczególnych typów edukacji 600 godzin. To dawało możliwość zaplanowania zajęć z poszczególnych przedmiotów 
z podziałem na dwa poziomy wiekowe (osobno dla dzieci w wieku przedszkolnym i osobno dla dzieci z klas I-III).

Nasz eksperyment dotyczył również zwiększenia liczby godzin w zakresie przedmiotów artystycznych, zwłaszcza z edukacji muzycznej. Na pierwszym roku zaplanowano 30 godzin chóru. W kolejnych latach realizowane były zajęcia z: wprowadzenia do edukacji muzycznej z nauką gry na instrumencie (30 godzin), podstaw gry na instrumentach klawiszowych (30 godzin), metodyki gry na instrumentach szkolnych (30 godzin). Oprócz tych przedmiotów w programie studiów zaplanowano metodykę zajęć rytmicznych (30 godzin). Celem tych zajęć było uzyskanie podstawowych umiejętności gry na instrumentach, które są bardzo przydatne w pracy nauczyciela przedszkolnego i wczesnoszkolnego. Ponieważ poziom wykształcenia muzycznego uczestniczek projektu był mocno zróżnicowany (niektóre ze studentek kończyły szkoły muzyczne), należało proces kształcenia dopasować do ich potrzeb i umiejętności. Podział na małe grupy i zwiększenie liczby godzin pozwoliły na osiągnięcie przez studentki zamierzonych efektów, co zostało potwierdzone uzyskaniem zaliczeń z tych przedmiotów.

Po trzech latach wdrażania innowacyjnego modelu, można stwierdzić, że integracja poszczególnych modułów (nastawionych na połączenie teorii z praktyką), zwiększenie liczby godzin na realizację treści, również większa liczba godzin przeznaczona na ćwiczenia połączone z praktyką w placówkach oświatowych (praca w małych grupach) spełniły swoje założenia. Studentki od pierwszego roku były świadome swoich kompetencji, co przedstawione zostało w raporcie z badań (Surma 2019). W toku kolejnych lat realizowano przygotowanie ich do pracy zespołowej. Zwrócono uwagę na rozwój kompetencji z zakresu technologii informacyjnej i komunikacyjnej. Nabyte kompetencje zostały pozytywnie zweryfikowane w trakcie przymusowego przejścia na nauczanie zdalne (Covid-19). W kolejnych latach ich kompetencje będą rozwijane w zakresie pracy z dzieckiem ze specjalnymi potrzebami, ale też z innowacyjnymi metodami. Rozłożenie procesu kształcenia nauczycieli na pięć lat, w porównaniu z systemem dwustopniowym, pozwala na systematyczne, ale też rzetelne i pogłębione przekazywanie treści, bez potrzeby ponownego rozpoczynania od podstaw.

$\mathrm{Na}$ podstawie obserwacji i analizy protokołów ocen można stwierdzić, że proces kształcenia w tym modelu przynosi zamierzone efekty. Studentki osiągają bardzo wysoką średnią w porównaniu z innymi rocznikami. Nauczyciele prowadzący zajęcia zauważają, że studentki bardzo dużo wymagają od siebie, ale też od swych wykładowców. Eksperymentalny program, oparty na propozycji modelu kształcenia nauczycieli, sprawdza się już na tym etapie jego realizacji.

W związku z tym kolejnym krokiem jest porównanie ze sobą dwóch dokumentów: „Propozycji modelu kształcenia nauczycieli przedszkolnych i wczesnoszkolnych” i „Rozporządzenia Ministra Nauki i Szkolnictwa Wyższego w sprawie standardu 
kształcenia przygotowującego do wykonywania zawodu nauczyciela” (Dz.U. 2019 poz. 1450), w celu wykazania różnic, które mogą się okazać istotne w procesie kształcenia nauczycieli.

\section{Różnice między propozycja modelu a standardami kształcenia nauczycieli}

Porównanie obu dokumentów dotyczyć będzie wskazania różnic w rozkładzie/podziale zajęć, liczbie godzin, zapisie efektów ogólnych i szczegółowych.

W rozporządzeniu w sprawie standardu kształcenia nauczycieli wyodrębniono 11 grup zajęć. W porównaniu z propozycją modelu kształcenia, po pierwsze zrezygnowano z podziału na moduły. Większa liczba grup zajęć wynika z innego podziału. $Z$ modułu drugiego „przygotowanie do integracji treści nauczania” wyodrębniono grupę zajęć z metodyk poszczególnych typów edukacji, dydaktyki nauczania zintegrowanego nauczania oraz wspierania rozwoju dzieci w wieku przedszkolnym. Wydzielenie tych grup zajęć wraz z podaniem nazw przedmiotów oraz przeznaczonej liczby godzin porządkuje kwestie związane z ustaleniem programu kształcenia. Dodatkowo zapisano grupę zajęć z metodologii badań naukowych; w propozycji zapisano ten moduł jako seminarium dyplomowe. Zajęcia z modułu ,język obcy" przygotowujące studentów do prowadzenia zajęć $\mathrm{z}$ języka angielskiego zostały przyporządkowane w rozporządzeniu do kilku grup zajęć, zgodnie z oczekiwanymi efektami i planowanymi treściami. W grupie zajęć z przygotowania psychologiczno-pedagogicznego przewidziano 60 godzin z psychologicznych i pedagogicznych podstaw nauczania dzieci języka obcego. W kolejnych dwóch grupach z przygotowania merytorycznego i metodyk poszczególnych typów edukacji studenci mają zrealizować 120 godzin w języka obcego i 60 godzin z metodyki nauczania języka obcego. W porównaniu z propozycją modelu zmniejszona została liczba godzin na przygotowanie merytoryczne z 240 godzin do 120 oraz o 60 godzin z psychologicznych i pedagogicznych podstaw nauczania języka obcego, co może spowodować obniżenie umiejętności językowych studentów. Dziecko w wieku przedszkolnym, ze względu na sposób nabywania przez nie języka (kształtowanie mowy), powinno mieć kontakt z osobami posługującymi się językiem obcym na bardzo wysokim poziomie.

W rozporządzeniu zmniejszono również liczbę godzin praktyk z 300 na 240, czy też metodyk z 600 na 480, z podstaw psychologii z 240 na 180. Ogólna liczba zajęć w rozporządzeniu wynosi 2800, a w propozycji była wyższa o 790 godzin (wynosiła 3590 , plus 20 godzin na zajęcia spersonalizowane z elementami tutoringu na jednego studenta). Zajęcia te zostały pominięte $\mathrm{w}$ standardzie kształcenia nauczycieli. Jest to istotna różnica, która na pewno będzie utrudniała nabywanie przez studentów 
kompetencji na wysokim poziomie w porównaniu z obecnie realizowanym programem eksperymentalnym. Uczelnie też nie otrzymują dodatkowych środków na prowadzenie zajęć w małych grupach, co również przynosiło pozytywne efekty.

W rozporządzeniu, w stosunku do propozycji modelu kształcenia nauczycieli, dopracowano zapis ogólnych efektów kształcenia i doprecyzowano szczegółowe efekty kształcenia z uwzględnieniem poszczególnych grup zajęć i przedmiotów. Dopisano trzy ogólne efekty kształcenia ściśle związane z metodologią badań, co było pominięte $\mathrm{w}$ drugim dokumencie. Natomiast w rozporządzeniu usunięte zostały efekty dotyczące m.in. edukacji międzykulturowej czy też alternatywnych form edukacji. W propozycji modelu kształcenia nauczycieli zwrócono też większą uwagę na ogólne efekty w zakresie technologii informacyjnej i komunikacyjnej oraz informatyki. W rozporządzeniu zostały one przeniesione do szczegółowych efektów kształcenia i przypisane do innej grupy przedmiotów.

\section{Wnioski}

Różnice występujące w rozporządzeniu, dotyczące zapisów efektów, są korzystne dla organizacji procesu kształcenia. Uszczegółowienie i przyporządkowanie efektów do konkretnych przedmiotów przyczyni się do ujednolicenia przygotowania nauczycieli przedszkolnych i wczesnoszkolnych w całej Polsce. W propozycji modelu kształcenia istniała dowolność w planowaniu zajęć i realizacji efektów kształcenia, czasami wymagania w stosunku do wskazanych przedmiotów nie można było połączyć z efektami kształcenia. W rozporządzeniu zostało to poprawione.

Okrojenie liczby godzin i mniejsza dotacja na prowadzenie studiów są dużym wyzwaniem dla uczelni. Utrzymanie wysokiej jakości kształcenia bez możliwości pracy w małych grupach i w mniejszym wymiarze godzin przeznaczonych na poszczególne przedmioty będzie wymagało większego nakładu pracy bezkontaktowej studentów.

\section{Bibliografia}

Czerepaniak-Walczak M. (1997). Aspekty i źródta profesjonalnej refleksji nauczyciela, Toruń: Wydawnictwo „Edytor”.

Gołębniak, B.G., Krzychała, S. (2015). Akademickie ksztatcenie nauczycieli w Polsce - raport z badań. „Rocznik Pedagogiczny”, s. 97-112.

Grzeszkiewicz B. (2002), W poszukiwaniu wzoru nauczyciela wychowania przedszkolnego, w: Kompetencje nauczyciela. Stan, potrzeby i kierunki zmian, red. E. Kozioł, E. Kobyłecka, Zielona Góra: Oficyna Wydawnicza UZ. 
https://archiwum.ncbr.gov.pl/fileadmin/POWER/03.01...PKN_18/zal._nr_6_Lista_rankigowa_pozytywna_PKN.pdf [dostęp: 12.02.2021].

https://www.gov.pl/web/edukacja-i-nauka/konkurs-ncbr-na-programy-ksztalcenia-nauczycieli [dostęp: 12.02.2021].

https:/www.gov.pl/web/edukacja-i-nauka/opracowanie-modelowych-programow-ksztalcenia-nauczycieli-w-ramach-dzialania-31-kompetencje-w-szkolnictwie-wyzszym, [dostęp: 12.02.2021].

Karbowniczek J., Kwaśniewska M., Surma B. (2011) Podstawy pedagogiki przedszkolnej z metodyką. Kraków: Wydawnictwo Ignatianum.

Pawelec L. (2017). Jakość przygotowania zawodowego nauczycieli w świetle badań empirycznych, „Annales Universitatis Mariae Curie-Skłodowska Lublin - Polonia”, vol. XXX, nr 2, s. 99-114, DOI: 10.17951/j.2017.30.2.99

Rozporządzenie Ministra Nauki i Szkolnictwa Wyższego w sprawie standardu kształcenia przygotowującego do wykonywania zawodu nauczyciela” (Dz.U. 2019 poz. 1450) http://isap.sejm.gov.pl/isap.nsf/DocDetails.xsp?id=WDU20190001450 [dostęp: 12.02.2021].

Rozporządzenie Ministra Nauki i Szkolnictwa Wyższego w sprawie standardu kształcenia przygotowującego do wykonywania zawodu nauczyciela" (Dz.U. 2012 poz. 131) https:// www.bip.nauka.gov.pl/g2/oryginal/2013_05/c49a61a9a3861e7a323901ff0849dff3. pdf [dostęp: 12.02.2021].

Surma B. (2011). Uczestnicy (podmioty) procesu edukacyjnego w przedszkolu, w: Karbowniczek J., Kwaśniewska M., Surma B., Podstawy pedagogiki przedszkolnej z metodyką. Kraków: Wydawnictwo Ignatianum, s. 158-172.

Surma B. (2019). Ksztattowanie kluczowych kompetencji nauczycieli edukacji elementarnej-raport z badań. „Edukacja Elementarna w Teorii i Praktyce”, 14(52), s. 93-104. https://doi.org/10.35765/eetp.2019.1452.06.

\section{ADRES DO KORESPONDENCJI}

Barbara Surma

Akademia Ignatianum w Krakowie

e-mail: barbara.surma@ignatianum.edu.pl 